\title{
MAGISTRI OR MAGISTRATVS? A PROBLEM IN HISPANO-LATIN EPIGRAPHY
}

\author{
¿MAGISTRI O MAGISTRATVS? \\ UN PROBLEMA EN LA EPIGRAFÍA HISPANO-LATINA
}

\author{
Leonard A. Curchin \\ University of Waterloo \\ lcurchin@uwaterloo.ca
}

DOI: $10.1387 /$ veleia.14987

\begin{abstract}
The epigraphic abbreviation $M A G$, when referring to the secular leaders of gentes and unprivileged towns, has been inconsistently interpreted by various authors as mag(ister), mag(istratus) or mag(isterium). A study of the meaning and usage of the terms magistri and magistratus suggests that the officials of vici, pagi and castella were called magistri, while those of gentes and unprivileged towns (oppida, civitates) were known as magistratus. This finding provides reliable criteria for determining the meaning of $M A G$ in particular cases.

Keywords: castella, élites, magistrates, oppida, pagi, peregrine towns, vici.

Resumen: La abreviatura epigráfica $M A G$, cuando se refiere a los líderes políticos de gentes y de comunidades no privilegiadas, ha sido interpretada de manera inconsecuente como mag(ister), mag(istratus) o mag(isterium) por varios autores. Un estudio del uso y de la significación de los términos magistri y magistratus concluye que los responsables de vici, pagi y castella se llamaban magistri, mientras que los dirigentes de gentes y de comunidades no privilegiadas (oppida, civitates) se llamaban magistratus. Este resultado proporciona criterios fiables para establecer la significación de $M A G$ en determinados casos.

Palabras clave: castella, comunidades peregrinas, élites, magistrados, oppida, pagi, vici.
\end{abstract}

Recibido: 08-02- 2015

Informado: 18-03-2015

Definitivo: 28-04-2015

Anyone who studies the Latin epigraphy of Hispania will be familiar with the problem of the ambiguous abbreviation $M A G$, which can mean either magister or magistratus ${ }^{1}$. In a phrase such as "per mag." or "mag. IIvir", which is the correct solution? Too often this question has been decided arbitrarily by educated guess or an editor's opinion, rather on sound principles. In some cases, scholars have disagreed as to the meaning of this abbreviation in a particular inscription. In others, the published expansion is couched in a query such as "mag(istrum?)" or "mag(istratus?)",

1 According to the list of epigraphical abbreviations on the website of the American Society of Greek and Latin Epigraphy (http://classics.case.edu/ asgle/bookshelf/abbreviations-in-latin-inscriptions/), $M A G$ can stand for mag(ister), mag(isterii), ma- g(isterio), mag(isterium), mag(istra), mag(istras), mag(istratibus), mag(istratu), mag(istratus), mag(istreis), mag(istri), mag(istris), mag(istro), mag(istrorum), ma$g$ (istros), mag(istrum); to which should be added mag(istratum). 
indicating that the editor is not really certain. In one inscription, from Idanha-a-Velha (discussed below), various authors have proposed four possible solutions for $M A G$. While in recent years there has been an increasing tendency to interpret the $M A G$ officials as "mag(istratus)", a considerable number of scholars still see them as "mag(istri)". Moreover, there are circumstances in which the interpretation "mag(istratus)" is not appropriate. The purpose of this article is to establish the difference between magistri and magistratus, and to provide a basis for deciding which expansion of $M A G$ is appropriate in particular cases.

\section{MAG: INVENTORY AND PREVIOUS INTERPRETATIONS}

The abbreviation $M A G$, referring to civic officials, occurs on inscriptions in stone or bronze dating from the Augustan era to the end of the first century A.D. Oddly, there are no examples of magistri or magistratus in Hispano-Latin coin legends. In this section we list 14 inscriptions in which local officials are designated as $M A G$. Most of these refer clearly to non-religious office holders, although four of the inscriptions are votive, and in a few of these cases it is unclear whether $M A G$ is a magistrate or a cult official.

\subsection{Provincia Lusitania}

a) Cáparra (Capera); A.D. 70-100. HAE 2574 = $A E$ 1967, $197=A E$ 2002, $705=H E p$ 12, 93: Aug[ustae] Trebar[unae] | M. Fidius Fidi f. Quir(ina) [Macer] | MAG III, IIvir II, praef(ectus) fa[brum ---]. Blázquez $(1965,59)$ developed $M A G$ as "mag(ister)", a solution accepted by Caballos Rufino (1998, 218-219). García y Bellido (1974, 9) opined that Fidius Macer was a magistratus. Hurtado de San Antonio (1977, nº. 818), Rodríguez Neila (1993, 387), González Herrero (2002, 425), Andreu Pintado $(2006,376)$ and Ortiz de Urbina $(2013,286)$ all read "mag(istratus)". However, Mantas (2000, 411), Salinas de Frías $(2001,194)$ and des Boscs-Plateaux (2005, 655 $\mathrm{n}^{\circ}$. 194) read "mag(ister)" 2 . M. Fidius Macer is known from two other inscriptions of Capera (CIL II, 834-835). The tribe Quirina and the title duovir imply that Capera was a Flavian municipium, though $M A G$, the first office held by Fidius Macer, could have antedated the municipal grant.

b) Âlvega (Aritium Vetus); A.D. 37. CIL II, $172=$ ILS 190: Oath of allegiance to the emperor Gaius, dated by the Roman consuls and by $M A G \mid$ Vegeto Taltici [f., V]ibio [M]arioni[sf.]. On this inscription, Hübner commented "Magistri duo fuerunt", thereby implying that $M A G$ should be expanded "mag(istris)", a reading adopted by $\operatorname{ILS}$. D'Ors $(1953,21)$ supplied "mag(istratibus)". The equivocal reading "mag(istris vel istratibus)" offered by Encarnação (1984, ${ }^{\circ}$. 647) has been retained by Rosado Martín (2010, 343), although Encarnação himself subsequently opted for "mag(istris)" (Encarnaçáo 2007, 357). Rodríguez Neila (1995, 263 n. 12) and Melchor Gil (2013, 146 n. 28) regard Vegetus and Vibius as magistratus. Aritium Vetus at this time had the status of oppidum ("in Aritiense oppido veteri", according to the same inscription).

c) Idanha-a-Velha (civitas Igaeditanorum); 16 B.C. $H A E 1063=A E 1967,144=A E$ 1992, $951=$ HEp 2, 770: Commemoration of the donation of a sundial (horologium) by Q. Iallius of

2 Des Boscs 2005, 202 n. 16, assumes that Fidius Macer was magister of some religious college. He could have been magister of the cult of Trebaruna. However, given the Flavian date and his subsequent career, it is more probable that $M A G$ refers to a civic office which Macer held prior to Capera becoming a municipium. 
Emerita, per MAG | Toutoni Arci f., | Malgeini Manli f., | Celti Arantoni f., | Ammini Ati f. Almeida (1956, 140), Lambrino (1956, 18) and Mantas (1988, 421-422) construed $M A G$ as "mag(istros)". However, the editors of $A E 1967$ felt that the genitives following $M A G$ demanded a development "mag(isterium)" or "mag(istratum)", and so printed "mag(isterium?)", a reading later adopted by Bonnin (2010, 186). Étienne (1992, 356-357) read "mag(istros)" but expanded the personal names as accusatives "Toutoni(um)", "Malgeini(um)", and so on. Ferrer Maestro (1991, 110) considered that the magistri in this inscription were the artificers who produced the sundial for the donor. However, Rodríguez Neila (1995, 263 n. 12), Melchor Gil (2011, 156), Pérez Zurita (2011, 209) and Ortiz de Urbina $(2013,291)$ interpreted these same men as magistratus. Recently, Encarnação (2013a, 213; 2013b, 127) has defended the reading "per mag(istros)", arguing that the magistri who accept the donation are representatives of four gentilitates, and that the personal names in the genitive are not the names of the magistri (who, being merely representatives, remain anonymous) but the names of the eponymous ancestors of each gentilitas (e.g. the gentilitas of Toutonus son of Arcus). By contrast, Castillo (2013, 300) suggests that "per" may not be a preposition but an abbreviation, and that we should understand "per(missu) m(agistratuum)". The town of the Igaeditani, possibly named among the Lusitanian municipia in a Trajanic inscription from the Alcántara bridge (CIL II, $760=I L S 287)^{3}$ was still an unprivileged civitas in the time of Augustus ( $A E$ 1961, 350). Numerous inscriptions mentioning the tribe Quirina show that it received Latin rights under the Flavians (Wiegels 1985, 80).

\subsection{Provincia Baetica ${ }^{4}$}

a) Villanueva del Río y Minas (Munigua); early first century A.D. ${ }^{5}$. HAE $1922=A E 1962$, 287 = CILA 2/4, 1053: Tabula hospitalis of Sex. Curvius Silvinus, quaestor pro praetore, with the senatus populusque Muniguensis, concluding: egerunt |L. Lucceius L. f. MAG| leg(atus) L. Octavius M. f. Silvanus. Nesselhauf $(1960,146)$ considered "mag(istratus)" likelier than "mag(ister)", while Galsterer (1971, 42) suggested "Mag(nus)", construing "leg(ati)" as referring to both men. D'Ors (1961, 203), González Fernández (1990, n. 20), Rodríguez Neila (1995, 263 n. 12), González Román (2002-2003, 91), Balbín Chamorro (2006, no. 72), Melchor Gil (2013, 147), Dopico Caínzos and Santos Yanguas (2013, 177 n. 21) all support "mag(istratus)". Munigua, amply attested as a Flavian municipium, would still have been an unprivileged town at the time of this inscription.

b) Cauche el Viejo (Aratispi); A.D. 38. CIL II $2 / 5,732=A E$ 1994, $923=$ HEp 6, 647: Tabula hospitalis between Q. Lucius Fenestella and the senatus populusque civitatis Aratispitana, concluding: egit | P. Vibius Rufinus $M A G$. Corell Badía and Corell i Vicent (1994) read "mag(istratus)", followed by Balbín Chamorro (2006, n. $\left.{ }^{\circ} 73\right)$, Dopico Caínzos and Santos

3 The transmitted text "Igeditani" is perhaps a misreading of "[Tur]d[e]tani". See Carbonell, Gimeno, Stylow 2007 = AE 2007, 716 = HEp 16, 62 .

4 I exclude the oath of loyalty to Augustus from Las Cabezas de San Juan (Conobaria) ( $A E$ 1988, $723=$ HEp 2, 623, HEp 5, $694=C I L A$ 2/3, 990), issued by T. Quinctius T.f. Silo, P. [--- MAG ---] senatus et populus Co[nobariensium], since the reading $M A G$ here is only conjectural.
5 D'Ors 1961, 206-207, dated this inscription to A.D. $5 / 6$, on the basis of its similarity to CIL II $1343=$ ILS 6097 (from Lacilbula, A.D. 5) and $A E$ 1952, 49 (from Emerita, A.D. 6). Nesselhauf $(1960,148)$ placed it between 27 B.C. and A.D. 40, while Alföldy 1969, 182-183, dated it to Augustus or Tiberius. On the career of Sex. Curvius Silvinus, see Schäfer 2000, 91. 
Yanguas (2013, 177 n. 22). CIL prints “mag(istratus?)", noting that one could equally understand "mag(ister)".

c) Bienvenida (Sisapo); first century A.D. $A E 1991,956=H E p$ 1, 81: Domina(e) | [A]ttaegina(e) | [T]urubriga(e) | [cul?]tiribus suis | collectis $\mid M A(G)$ f(ecerunt?) $\mid s(---)$. For $M A$ in the penultimate line, López Melero (1986) suggested, among other possibilities, “ma(gistri)", a proposal adopted by $A E$ and $H E p$. While the inscription is clearly dedicated (with some variation in spelling) to the amply attested deity Ataecina of Turobriga ${ }^{6}$, it is unclear whether the $M A(G)$ are magistri of the cult, or magistrates of Sisapo. Pliny $(N H 3,14)$ lists Sisapo as an oppidum.

\subsection{Provincia Tarraconensis ${ }^{7}$}

a) O Courel (also spelled Caurel), Lugo; A.D. 28. $H A E 1965=A E$ 1961, $96=A E$ 2000, 748: Tabula hospitalis between Tillegus Ambati f. Susarrus of the castellum Aiobrigiaecum and the Lougei castellani Toletenses, enacted by Tillegus Ambati ipse |MAG Latino Ari (f.) et Aio Temari (f.). Arias Vilas et al. (1979, $\left.\mathrm{n}^{\circ} .55\right)$, Zeidler $(2007,45)$ and Gómez Vila (2009, n. 18) read "mag(istris)". However, D’Ors (1960, 144) and Rodríguez Neila (1995, 236 n. 12) believed these officials were magistratus. Balbín Chamorro (2006, $\mathrm{n}^{\circ}$. 50), Martínez Melón (2006, 124 n. 138), Dopico Caínzos and Santos Yanguas (2013, 176 n. 17) likewise read "mag(istratibus)", while García Martínez $(1997,43)$ lists both possibilities.

b) La Milla del Río, León; first century A.D. CIL II, 2636 = ILS 4509: Deo | Vagodonnaego (or Vago Donnaego) | sacrum res p(ublica) | Ast(urica) Aug(usta)| per MAG G(aium) Pacatum | et Fl(avium) Proculum | ex donis || curante Iulio Nepote. CIL, followed by Diego Santos (1986, $\mathrm{n}^{\circ}$. 63) and Hernández Guerra (2008, 418 n. 53), expanded "mag(istros)". Fernández Aller (1978, $\mathrm{n}^{\circ}$. 14), followed by Mañanes Pérez (1982, $\left.\mathrm{n}^{\circ} .108\right)$, Wiegels (1985, 93), Rodríguez Neila (1995, 263 n. 12) and González Rodríguez $(2014,210)$ read "mag(istratus)" (cf., ineptly, "mag(istratos)" in Rabanal Alonso 1998, 118). According to Reid (1913, 236), magistri is a title of the chief magistrates, indicating that Asturica was at first organized as a native rather than Roman town. Similarly, Olivares Pedreño (2002, 102; 2002-2003, 214) read "mag(istros)" but believed they were magistrates ${ }^{8}$. On the contrary, Pastor Muñoz (1977, 172), followed by Curchin (1990, 239-240), considered it likely that magistri referred to a religious college of Asturica. Mangas (1997, 194) saw them as officials in charge of cult places, citing Lex Ursonensis chapter 128, which provides that the duovirs, aediles or prefects will arrange for the appointment of "mag(istri) ad fana, templa, delubra" (CIL II $2 / 5,1022$ = ILS 6087). However, it does not follow that the religious institutions in a Roman colony like Urso would necessarily be found in the towns of Asturia. Also, although several magistri fani are attested in central Italy ${ }^{9}$, our inscription says only $M A G$, not $M A G$ fani. Two magistri collegi(i) are named on another inscription of Asturica $(A E 1928,167)$,

6 On the numerous other dedications to Ataecina Turobrigensis, see Abascal 2002, 53-54. The ruins of Turobriga have been identified in the Llanos de San Mamés near Aroche, Huelva.

7 I exclude an inscription from Montealegre de Campos, Valladolid dated A.D. 134 ( $A E$ 1985, $581=A E$ 1994, $1005=H E p$ 1, $645=H E p$ 6, 987), renewing hospitium between Amallobriga and the senatus populusque Caucensium. The initial publication by
G. Bravo Castañeda 1985, interpreted $M A G I$ at the end of line 6 as magi(stri) or magi(stratus), whereas it is really part of the phrase cognationis Magi|lancum.

8 "La ofrenda se realiza, por tanto, por dos magistrados de la Res Publica Asturica Augusta" (Olivares Pedreño 2002-2003, p. 214).

9 CIL X, 3918, 3924, 3988 (magistri fani Dianae at Capua), 4620 (magister fani Iunonis at Cubulteria). 
though without indication of the nature of the collegium. The $M A G$ inscription was carved on four marble plaques found in 1816 at La Milla del Río (about $20 \mathrm{~km}$ north-east of Astorga), a site with mosaics and remains of buildings, but there is nothing (apart from the inscription itself) to suggest that it may have been a fanum, templum or delubrum. It may have been a Roman villa (Tranoy 1981, 299). Pliny (NH 3,28) describes Asturica Augusta as urbs magnifica, which gives no clearer indication of its juridical status than the ambiguous term res publica in this inscription. Several inscriptions mentioning the tribe Quirina suggest that the city was a Flavian municipium (Wiegels $1985,92)$.

c) Herrera de Pisuerga (Pisoraca); A.D. 14. HAE $2452=A E$ 1967, $239=A E$ 2002, 785 = HEp 12, 363: Zoomorphic tessera hospitalis between the $M A G$ et senatus Maggavienses and Amparamus Nemaecanus Cusaburensis, enacted per MAG Caelione(m) | et Caraegium et Aburnum. Galsterer $(1971,53)$ admitted that $M A G$ could mean either "mag(istros)" or "mag(istratus)". García y Bellido $(1966,152)$ read "mag(istratus)", followed by González Rodríguez $(1986,132)$, Hernández Guerra (1994, nº 114), Rodríguez Neila (1995, 263 n. 12, where the date "13 d.C." is a misprint), Marco Simón (2002, 169-170), Balbín Chamorro (2006, no. 53), Dopico Caínzos and Santos Yanguas $(2013,174$ n. 11). The town involved is described in the same inscription as civitas Maggaviensium.

d) Paredes de Nava, Palencia; 2 B.C. Eph. Epig. I (1872), 141 = CIL II, 5763 = ILS 6096: Tessera hospitalis between Acces Licirni (f.) of Intercatia with the civitas Palantina, per $M A G$ Elaisicum. Emil Hübner in Eph. Epig. expanded $M A G$ as "mag(istratum)", but in CIL changed it to "mag(istrum)", explaining that the hospitium was enacted "per magistrum sive magistratum". The fact that "magistratum" is not in italics signifies that it is Hübner's explanation of magistrum rather than an alternative expansion of the abbreviation. More recently, D'Ors $(1953,369)$, Solana Sainz (1981, 39 n. 48), Hernández Guerra (1994, no. 112), Rodríguez Neila (1995, 263 n. 12), Beltrán Lloris (2001, 43), Balbín Chamorro (2006, no. 51), Pérez Zurita (2011, 209), Dopico Caínzos and Santos Yanguas (2013, 172 n. 2) read mag(istratum). Palantia eventually received municipal status under Vespasian, as disclosed by the tribe Quirina (Wiegels 1985, 127) ${ }^{10}$.

e) Peñalba de Castro (Clunia); early first century A.D. ${ }^{11}$. CIL II, 2782 = Clunia II, 28: C. Calvisio Aiionis f. Gal(eria) | Sabino MAG, flamini Romae | et divi Augusti. Calvisius was "mag(istro)" according to Hübner, followed by Palol and Vilella (1987, no. 28), but magister of what? There is no attestation anywhere in the Empire of a magister Romae et Augusti. The balance of probability is that Calvisius is a local magistrate; thus Gómez-Pantoja $(2003$, 254) reads "mag(istratus)". Mention of the tribe Galeria, together with indication of his father's indigenous name, shows that C. Calvisius Sabinus, who is also honoured in a first-century inscription at Uxama (CIL II, 2822), acquired Roman citizenship in the Julio-Claudian period. Clunia may have received municipal status under Tiberius (Galsterer 1971, 35), since local coinage under that emperor designates IIIIviri and aediles, or possibly under Augustus (Wiegels 1985, 162). Perhaps significantly, it was not until late in the reign of Tiberius that a road was built linking Clunia to Caesaraugusta ${ }^{12}$. In any event, the title flamen Romae et divi Augusti cannot be earlier than Tiberius, though it is possible that the office of $M A G$ was held earlier.

10 To the two examples cited by Wiegels, add "C. Antonio Calaedi f. Q(uirina) Festo" ( $A E$ 1987, 615a = HEp 2, 607).

11 Reign of Tiberius, according to Étienne 1958, 205 and Gómez Pantoja 2003, 252.
12 Three milestones in Soria province attest construction of this road in A.D. 33/34 (Lostal Pros 1992, 42-44 and Mapa 3). 
f) Arellano, Navarra; mid-first century A.D. $A E$ 1951, 281: Altar with metric inscription recording successful completion of a vow to Iuppiter Appenninus during a trip to Rome by one Flavus MAG victor et laetus. Navascués (1934, 193-195) interpreted $M A G$ as the cognomen "Mag(ilo?)", followed by Mariner (1952, 213-214), Castillo et al. (1981, n. 18) and Cugusi $(1985,20)$. However, Mayer and Velaza propose reading "Flavus mag(istratus)", explaining that the inscription alludes to "una legatio por cualquier motivo realizado por un comisionado de una comunidad» (Mayer and Velaza 1994, 521). While it is not known to which community Flavus might have belonged, the likeliest candidate is Curnonium ${ }^{13}$, plausibly identified with the 25-hectare archaeological site of El Castillo at Los Arcos, $11 \mathrm{~km}$ south-west of Arellano ${ }^{14}$. It should be noted that there were no privileged towns in Navarra in the mid-first century ${ }^{15}$.

g) Alcalá de Henares (Complutum); late first century A.D. CIL II, 2033: Cn. Nonio|C. Noni fil.| Quir(ina) Crescent[i] | MAG, flamin[i] |Romae et Aug(usti)|d(ecreto) d(ecurionum). GonzálezConde (1985, 135), Knapp (1992, n. 120), Ruiz Trapero (2001, nº 14) and Royo Martínez (2010, 380 n. 6) all read "mag(istro)". The tribe Quirina reflects the status of Complutum as a Flavian municipium. As in the inscription from Clunia discussed above, we have the formula $M A G$, flamini Romae et Augusti. According to G. Alföldy, it is unlikely that $M A G$ indicates the magister of a collegium. Therefore, he argues, since the title magister is inappropriate to a municipium, either Nonius was magister of a vicus in the territory of Complutum, or he was magister at Complutum before it became a municipium, and flamen afterward (Alföldy 1987b, 63). While Alföldy does not consider the possibility that $M A G$ represents "mag(istratui)", Rodríguez Neila (1995, 263 n. 12), Andreu Pintado $(2003,170)$ and Melchor Gil $(2011,157)$ all accept the identification of Cn. Nonius Crescens as a mag(istratus).

h) Caracuel de Calatrava (Carcuvium); first century A.D. $A E$ 1987, $686=H E p$ 2, 280: [---] | M. C[---] | Gal(eria) Flavu[s] | M. Valeriu[s] Proculus | MAG II. According to Alföldy (1987, 236-237), Carcuvium, a mansio known from the Antonine Itinerary (IA 445,1), would have been a vicus in the territory of Oretum. Therefore the two named men would be magistri vici. One of them belongs to the tribe Galeria, assigned to persons receiving Roman citizenship under the Julio-Claudians.

\section{MAGISTRI}

The term magister (apart from magistri grammatici) ${ }^{16}$ most often refers to an official of a religious college, such as the magistri Larum (Augustales) ${ }^{17}$ or, at Saguntum, the magistri Saliorum ${ }^{18}$. Not infrequently, magistri were also seviri Augustales ${ }^{19}$. The presence of magistri in some other cults may be suspected, for instance in the dedication to (Sol) Deus Invictus by Messius Artemidorus,

13 Ptol. 2,6,66; CIL XIII, 621, Bordeaux (Curnoniensi); cf. $H E p$ 7, 479, Tafalla (Cur(noniensi)?).

14 Armendáriz Martija 2006; cf. Ramírez Sádaba 2006, 191 and Mapa n. ${ }^{\circ}$ 4, who places Arellano in the territory of Curnonium.

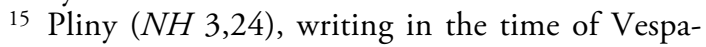
sian but using earlier sources, lists the Andelonenses, Carenses and Pompelonenses as populi stipendarii. Pompaelo was still a civitas in A.D. 57 (CIL II, $2958=$ ILS 6104).
16 CIL II'2/7, 336; CIL II'2/14, 377, 1282.

17 Baetica: CIL II, 1133; CIL II ${ }^{2} / 5$, 773; CIL II ${ }^{2} / 7$, 204, 323, 324, 327; HEp 9, 508. Tarraconensis: CIL II, 3113; CIL II $2 / 14,1242$, 1247, 1251, 1253, 1261, 1262, 1264, 1266, 1267; HEp 10, 292.

18 CIL II $2 / 14,349,364,365,690$. On the role of the magister as president of the college of Salii, see Delgado Delgado 2014, 159.

19 CIL II $2 / 14,1242,1243,1251,1253,1256,1259$, $1261,1263,1266,1267$. 
magister (AE 1984, 465). There are also inscriptions in which an individual is designated magister collegii (referring to either a religious, professional or funerary association) or simply magister; in nearly all cases this involves a slave or freedman ${ }^{20}$.

Magistri can also appear in a civil context, denoting the officials in charge of a vicus or pagus ${ }^{21}$. These types of settlement, because of their small size and consequent lack of dignitas, were not autonomous entities but were rather attached to larger civitates $^{22}$. Consequently, their officials lacked the dignitas of magistrates, and were instead known as magistri. This would explain the title $M A G$ in the inscription from Carcuvium (vicus). A bronze decree of Hadrianic date from Agón (Zaragoza) prescribing irrigation regulations for several pagi (pagus Gallorum, pagus Belsinonensis, pagus Segardinensis) in the territories of Caesaraugusta and Cascantum, contains both the abbreviated phrase MAG pagi and full mention of magistri pagi ${ }^{23}$. At Garlitos (Mirobriga) in the late first or early second century we have explicit mention of two magistri pagi ${ }^{24}$. Later in this article it will be argued that castella also had magistri, a fact with possible implications for the $\mathrm{O}$ Courel inscription.

The abbreviation $M A G$ for magister in these contexts poses no problem. The difficulty arises when $M A G$ refers to the officials of a peregrine community (such as a gens, civitas or oppidum stipendiarium ${ }^{25}$. Much of the confusion is due to Emil Hübner, editor of CIL II, who seems to have subscribed to the belief that unprivileged political entities did not have magistratus. Despite the explicit mention of magistratus Zoelarum on a tabula hospitalis from Astorga with consular dating of A.D. 27 (see below), Hübner insisted on expanding $M A G$ as mag(istri) in the inscriptions from Aritium Vetus, La Milla del Río, and Paredes de Nava. His auctoritas undoubtedly inspired later investigators to interpret $M A G$, referring to civil officials, as mag(istri) in other inscriptions discovered subsequently.

\section{MAGISTRATVS}

Apart from mentions of magistratus in colonial and municipal laws (such as the Lex Ursonensis and Lex Irnitana) and on the Tabula Siarensis ${ }^{26}$, where the word is used as a generic term embracing the duovirs, aediles and, where applicable, quaestors of privileged cities, several literary

20 Religious: IRPac. 146 (dedication to Venus); $A E 1983,470=H E p$ 2, 810 (dedication to Dea); $A E$ 1984, 465 (dedication to [Sol] Invictus). Professional, connected to commerce or production: $A E 2003$, $970=H E p$ 11, 621; CIL II, 3433-3434; HEp 1, 487; cf. Díaz Ariño 2004, 465-468. Funerary, with religious overtone (sacerdos familiae publicae, perpetuus magister): CIL II2/7, 315; cf. Santero Santurino 1978, 52-53. Unclear: $C I L$ II, 5007; $C I L \mathrm{II}^{2} / 14,1200,1270$; $A E$ 1928, 167; $A E$ 1990, $511=H E p$ 4, 169.

${ }^{21}$ Magistri vici are mostly found in neighbourhoods of cities like Rome and Pompeii, but occasionally in provincial villages, such as the magistri vici Eburomagi in Narbonensis $(A E 1969 / 70,388)$ and a magister vici Bodatii in Belgica (CIL XIII, 4310). Magistri pagi, by contrast, are widely attested. Cf. Tarpin 2001, 278-281 (magistri vici), 287-289 (magistri pagi).
22 "Vici, castella et pagi hi sunt qui nulla dignitate civitatis ornantur sed ... propter parvitatem sui maioribus civitatibus attribuuntur" (Isid. Etym. 15,2,11).

${ }^{23} A E 1993,1043=A E 2006,676=H E p 9,612=$ $H E p$ 13, 731. For a detailed study of this inscription, see Beltrán Lloris (2006).

${ }^{24}$ CIL II $^{2 / 7}, 875=A E$ 1986, $314=$ HEp 5, 72: C. Caecilius Pic|us et L. Sempr|onius Pollio | pagi magistri $\mid$ Iovi $O$ (ptimo) $M$ (aximo) vo|verunt.

25 The bizarre notion of A.M. Canto 1996, 318, that Pliny's oppida stipendiaria were not "unprivileged" or "peregrine" towns but rather municipia which had recently received Latin status under Vespasian, has been convincingly refuted by García Fernández 2000.

26 "mag(istratus) et legatos municipiorum et coloniarum": $A E$ 1999, $891=H E p$ 9, 524, frag. II, col. b, lines $24 / 25$. 
and epigraphic sources provide explicit evidence for unprivileged towns or peoples of Hispania having magistratus:

a) In 49 B.C., Caesar summoned the magistratus principesque omnium civitatum of Hispania Ulterior to a meeting at Corduba (Caes. Bell. civ. 2,19). At this time, most of the towns in this province would have been peregrine.

b) Las Merchenas, Salamanca; Late Republic. HAE $1051=C I L \mathrm{I}^{2}$, 3466: Tes(s)era | Caurie(n) sis | magistratu |Turi. While previous editors (Alonso Ávila and Crespo Ortiz 1999, nº 184; Hernández Guerra 2001, $n^{\circ}$. 195) understood "magistratu Turi(o)" "when Turius was magistrate", it is possible to construe magistratu Turi as "during the magistracy of Turos" (so Balbín Chamorro 2006, no. 28). Alternatively, Turi might be a toponym, cognate with Turiaso, Turibriga and the river Turia (cf. Abascal 1995, 100). Caurium, modern Coria, is listed as a stipendiary town in Pliny, $N H 4,118$.

c) Astorga (Asturica Augusta); A.D. 27. CIL II, 2633 = ILS 6101: Renewal of hospitium between two gentilitates of the gens Zoelarum, enacted per Abienum Pentili magistratum Zoelarum. Both the magistrate of the Zoelae and the six men who conclude the agreement have peregrine names. The Zoelae are listed by Pliny $(N H 3,28)$ as one of the 22 populi of the Astures, together with the Gigurri, who are called gens on the El Bierzo decree (gente Gigurrorum: $H E p$ 7, $378=A E 2000,760)$. Pliny later $(N H 19,10)$ refers to the Zoelae as a civitas of Gallaecia. The near-synonymous terms populus and gens refer to a suprafamilial group occupying a particular district, with a town (oppidum) or place of assembly (forum, e.g. Forum Gigurrorum: Ptol. 2,6,37; Rav. 320,8) at their centre. The Zoelae eventually had their own senate, the ordo Zoelar(um) (CIL II, 2606). The word civitas is more ambiguous, referring to anything from an unurbanized tribal district to a city-state (Mangas 2000, 57-58)27. A parallel for the magistratus Zoelarum as official in charge of a gens, populus or civitas is afforded by "Flav(u)s Vihirmatis fil(ius) summus magistratus civitatis Batavorum" in Germania Inferior in the first half of the first century A.D. (CIL XIII, 8771). The Batavi are listed by Pliny $(N H 4,106)$ and Tacitus $($ Germ. 1,29) as one of the gentes of Germania.

d) Botorrita (Contrebia Belaisca), 87 B.C. Tabula Contrebiensis $($ AE 1979, $377=$ HEp 5, 914): This famous inscription records a judgement (sententia) by the senate of Contrebia, with the approval of the provincial governor, concerning the right of the Sosinestani to sell land to the Salluienses, and of the latter to dig a canal. The magistratus Contrebienses who witness the decision consist of one praetor and five others who are simply styled magistratus.

Inscriptions from Africa provide explicit evidence for magistratus as the title of civic magistrates in peregrine towns: C. Arruntius Faustus Arrunti Proculi f., magistratus of the res publica Silensium in Numidia (CIL VIII, 5884 = ILS 3906 = ILAlg. II, 6865); P. Ligarius Potitus Ligari Maximi f., decurion and magistratus annualis of the civitas Goritana in Africa Proconsularis (CIL VIII, $12421=$ ILS 5071); P. Cornelius Viator and Iustus Bithes, magistratus of the civitas Sivalitana in the same province $(A E 1996,1706)$. As Tissot $(1883,216-218)$ pointed out long ago with reference to the first two examples, the term magistratus designated the officials of a unit that was superior to a pagus but inferior to a municipium; in other words, an unprivileged town.

27 Although civitas theoretically denotes a political entity while gens and populus refer to social groups, the Romans applied these terms unsystematically to indigenous organizational units, often referring to the same people by all three terms (see Rodríguez Álvarez 1993, 456 with n. 19-21). On the distinction between gens and civitas Zoelarum, see González Rodríguez 1994, 162-163; González Rodríguez 2006, 70-71. 


\section{MAG: TOWARDS A SOLUTION}

In section 1 we listed 14 inscriptions in which local officials are designated $M A G$. These officials occur sometimes individually (at Capera, Munigua, Aratispi, Palantia, Clunia and Complutum), sometimes in pairs (Aritium Vetus, Asturica and the castellum Toletensium). They number three at civitas Maggaviensium, and four at civitas Igaeditanorum. The contexts in which these officials are recorded include votive inscriptions (Capera, Sisapo, La Milla del Río, Arellano), honorific inscriptions (Clunia, Complutum), hospitality agreements (Munigua, Aratispi, the castellum Toletensium, Herrera de Pisuerga and Paredes de Nava), oath of loyalty to the emperor (Aritium Vetus), and donation of a sundial (civitas Igaeditanorum). Although many of the inscriptions come from Galicia or the northern Meseta, one can no longer subscribe to the view of Galsterer that mag(istri) or mag(istratus) are found only in the North-west, in what he calls "the still rather barbaric part of Tarraconensis" 28 .

While some scholars have advocated the reading "mag(istratus)" in these inscriptions, others have insisted on retaining the traditional reading "mag(istri)". What particularly strikes the attentive observer who studies these inscriptions is the inconsistency of the approach: scholars have often been content to repeat the solution offered by their predecessors, which has become the communis opinio, even when it defies logic. Why, for instance, should the representatives of the Maggavienses in the inscription from Herrera de Pisuerga be universally accepted as mag(istratus), when the $M A G$ officials of larger towns such as Clunia and Complutum have been identified by the majority of scholars as mag(istri)? While those who advocate the interpretation of $M A G$ as mag(istratus) undoubtedly feel that their solution is the correct one, there are other recent scholars (e.g. Mantas 2000; Ruiz Trapero 2001; Salinas de Frías 2001; des Boscs-Plateaux 2005; Zeidler 2007; Encarnação 2007 and 2013a-b, Gómez 2009; Royo Martínez 2010) who do not share this view and who favour the expansion mag(istri) in some of these inscriptions. Of course, it is possible that $M A G$ could mean mag(istratus) in some inscriptions and mag(istri) in others, but if so, we would need reliable criteria for deciding the correct solution in each case.

What these $M A G$ inscriptions have in common is that they all refer to communities that, to the best of our knowledge, were unprivileged prior to the Flavian period. All except two of the inscriptions are probably pre-Flavian. The two Flavian examples, from Capera and Complutum, involve men who could have been $M A G$ prior to the grant of municipal status by Vespasian, and certainly prior to the receipt of their city's charter under Domitian. The four unabbreviated mentions of magistratus cited in section 3, as well as the African parallels, similarly refer to unprivileged communities.

The case of M. Fidius Macer of Capera is important, because after being $M A G$ he was subsequently duovir. This suggests he served as magistrate when the town was still unprivileged; after it received Flavian grant of municipium, he held the duovirate, thereby receiving Roman citizenship per honorem ${ }^{29}$. Cn. Nonius Crescens of Complutum also seems to have been $M A G$ before the Flavian grant of municipium to his town, after which he became a priest of the imperial cult. The inscription of C. Calvisius Sabinus of Clunia cannot be earlier than the reign of Tiberius,

\footnotetext{
28 "handelt es sich immer um Inschriften aus dem nordwestlichen, im 1 . Jh. noch ziemlich barbarischen Teil der Tarraconensis" (Galsterer 1971, 43 n. 48).

29 A possible parallel is provided by an inscription from Volubilis in Mauritania $(A E$ 1916, $42=A E$ 1992,
}

1943), concerning a Punic magistrate (sufes) who became duumvir and received Roman citizenship under the emperor Claudius when the city was made a municipium. 
since he was priest of the deified Augustus, but his office of $M A G$ presumably antedates the grant of municipal status to that town. Since Tiberian coins of Clunia were issued by IIIIviri and aediles, Calvisius Sabinus must have been $M A G$ either in the earlier part of Tiberius' reign, or else under Augustus. These three men (Fidius Macer, Nonius Crescens, Calvisius Salvinus) are the only $M A G$ officials displaying a voting tribe, emblematic of Roman citizens ${ }^{30}$. However, it is unclear how Nonius Crescens and Calvisius Sabinus received Roman citizenship. According to the Flavian Municipal Law ( $A E$ 1986, 333, chap. 21) citizenship was granted for holding a magistracy after the town became a municipium. There is no legal provision for citizenship grants to flamines, nor to those who had been local magistrates when the town was still peregrine. Nevertheless, these two individuals may have been recipients of viritim grants in recognition of their civic service. C. Calvisius Sabinus, for instance, was a noted benefactor who distributed grain to the people of Clunia when the price was high ("populo frumentum annona cara dedit") and was also honoured by the decurions of Uxama "ob plurima in rem publicam merita" (CIL II, 2822).

Rodríguez Neila $(1993,387)$ explained the title magistratus as belonging to a town's "premunicipal" phase. Similarly, Melchor Gil $(2011$, 154) has proposed that the term magistratus was used to refer to those who held power in unprivileged communities, although these could also be known by indigenous titles. In view of the unprivileged status of the towns in the $M A G$ inscriptions, as well as the explicit term magistratus in several other texts, these interpretations would serve to explain the $M A G$ officials as mag(istratus). Obviously, the magistrates of peregrine communities could not legitimately call themselves duoviri or quattuorviri, as they had not yet received a grant of colonial or municipal status. For the civic officials of these towns, the more general term magistratus was appropriate. None the less, it is noteworthy that in several towns they are attested in pairs, and at civitas Igaeditanorum in fours, as if in emulation of duoviri and quattuorviri ${ }^{31}$. The solution mag(istratus), a title appropriate to the civil officials of unprivileged towns, seems to fit most of our examples.

The position of magistratus in the local political hierarchy varied from place to place. Caesar, already cited, mentions magistratus principesque in all the civitates of Hispania Ulterior. In the Tabula Contrebiensis, the six local magistrates (all with indigenous names) comprise one praetor and five magistratus. This unusual number perhaps reflects a pre-Roman institutional structure, like the three magistrates of Maggavia(?) in the inscription from Herrera de Pisuerga. The office of praetor is attested at Saguntum in 219 B.C. (Livy 21,12,7), while a pair of praetors appear at Bocchoris in A.D. 6 (CIL II, 3695) ${ }^{32}$. In the hospitality tablet from Munigua, it is unclear whether the town is represented by one mag(istratus) and one legatus, or whether the legatus (with the very Roman-looking name L. Octavius M. f. Silvanus) is the representative of the honorand, Sex. Curvius Silvinus.

\footnotetext{
30 On the evidence for the Roman voting tribe (tribus) as an indicator of municipal promotion in the imperial period, see Le Roux 2010; Fasolini 2012.

31 It can be deduced from a famous letter of Vespasian in A.D. 77 (CIL II, $1423=C I L \mathrm{II}^{2} / 5,871=$ ILS 6092), addressed to the quattuorviri and decurions of Sabora but published by the duoviri, that the title quattuorviri included both duovirs and aediles. This supposition is verified by the title IIIIvir aedilicia potes-
}

tate in an inscription from Gades (CIL II, $1728=I L S$ 8131).

32 Possible pairs of praetors are named on coins of Calagurris and Celsa in the latter half of the first century B.C. (Curchin 1990, nº 523-524, 606-613), but it is unclear whether to read "pr(aetores) IIvir(i)" or "pr(aefecti pro) IIvir(is)". Both solutions pose problems: how could the coining magistrates be praetors and duovirs at the same time? Or why have both duovirs been replaced by prefects? 
In a few instances we find the prepositional phrase "per $M A G$ ". At Pisoraca, where this is followed by three names, we should understand "per mag(istratus)". In the inscription from Paredes de Nava, where it is followed by a single name, "per mag(istratum)". The example from the civitas Igaeditanorum is more complicated because "per $M A G$ " appears to be followed by four genitives. While I am convinced that we are dealing here with magistratus, not magistri, and that "per" is a preposition rather than an abbreviation for "per(missu)", it remains doubtful whether to read "per mag(istratum) Toutoni, etc.", understanding "mag(istratum)" in the sense of "magistracy", or "per mag(istratus) Toutoni(um), etc.", expanding the genitives into accusatives. However, the wording "per magistratum + genitive" is awkward and does not appear in inscriptions anywhere in the Empire. And while the name Celtius is amply attested, we have epigraphical evidence in Lusitania for the nominative forms Toutonus, Malgeinus and Amminus ${ }^{33}$ (never Toutonius, Malgeinius, Amminius, though the genitives Toutoni, Malgeini, Ammini are ambivalent) ${ }^{34}$; so the accusatives would not be Toutonium, etc. but Toutonum, Malgeinum, Amminum. In place of the existing hypotheses, I would suggest that the drafter of this inscription was not entirely fluent in Latin and inadvertently used the wrong grammatical case (genitive instead of accusative) after "per". Therefore, using the standard epigraphical convention for correction of letters inscribed erroneously, we should read: "per mag(istratus) Touton<um> Arci f., Malgein<um> Manli f., Celti<um> Arantoni f., Ammin<um> Ati f.".

Mentions of $M A G$ in the votive inscriptions from Sisapo and La Milla del Río are more ambiguous, since they could be either magistri or magistratus. The altar from Sisapo dedicated to the indigenous goddess Attaegina Turubriga by two $M A(G)$ might certainly refer to magistri of her cult rather than to local magistrates. In the inscription from La Milla del Río, considering that the officials who act on behalf of the res publica Asturica Augusta make a dedication to the indigenous god Vagodonnaegus, and that the inscription was found in a rural setting some distance from the town, it could be argued that they are magistri of the god's cult. However, just as religion in Latin municipalities was the responsibility of the duovirs ${ }^{35}$, so in peregrine communities - particularly if they were endeavouring to emulate the institutional models of privileged towns - religion may well have been the responsibility of their counterparts, the magistratus. The mention of "ex donis" in the La Milla del Río inscription suggests that the dedication may be the result of a public subscription by the inhabitants of Asturica Augusta ${ }^{36}$. Thus, while certainty is unattainable, there is good reason to believe that in the texts from Sisapo and La Milla del Río we are dealing with mag(istratus). In support of this hypothesis, it can be argued that the magistri of an indigenous deity would not likely wield sufficient authority to act as official representatives of a res publica.

A special problem is posed by the tabula hospitalis from O Courel, issued by the Lougei castellani Toletenses ("the Lougei of the castellum of the Toletenses", or "the castellani Toletenses

33 Toutonus Arconis f. (Almeida 1956, $\mathrm{n}^{\circ}$. $63=H A E$ 1113); cf. dative Toutono Matuceni $\mathrm{f}$. (HAE 927); [H]elvius Malgeinus (Eph. Epig. IX, 173); [Ma]lgei[nus] (Encarnaçáo 1984, $\mathrm{n}^{\circ} .476$ ); Malgeinus Leuri f. $(A E 1985,517=H E p$ 1, 698); [M]ailg[e]nus [C] umel[i f.] $(A E$ 1987, 482b = HEp 2, 903); Malgeinus [Ba] ti (f.) (Vaz 1997, no. 36); cf. datives [M]alce(i)no [Ma]aelonis (f.) $(A E$ 1990, 520), Malgeino Bovi [f.] $(A E$ 2000, $689=H E p$ 10, 727); Amminus Andaitiae f. (CIL II, 454); Amminus Taltici f. $(A E$ 1984, 468); T. Iulius Amminus (HEp 6, 485).
34 Vallejo Ruiz 2005, 132 and Grupo Mérida 2003, 84 list a nominative Amminius, but the only evidence they cite is the $M A G$ inscription from Idanhaa-Velha!

35 "[En] las comunidades latinas ... los responsables de la religión municipal fueron los duumviri" (Le Roux 2009, 278).

36 "es incontestable el carácter público y oficial de la dedicación al dios Vago Donnaego por parte de la ciudad de Asturia Augusta a través de sus magistrados" (González Rodríguez 2014, 212). 
belonging to the Lougei") ${ }^{37}$. The Lougei, in whose territory this castellum was located, were an ethnic subdivision of the Astures, attested as civitas Lougeiorum on a tabula hospitalis of A.D. 1 $(A E 1984,553=H E p 1$ 1, 458). The document from $\mathrm{O}$ Courel is signed by two $M A G$ officials, Latinus Ari f. and Aius Temari f. Are these men "the magistrates of the Lougei castellani Toletenses" (Salinas 2013, 27), or are they magistrates of the civitas Lougeiorum who act as guarantors of the transaction (Beltrán Lloris 2003, 45-46)? Scholars have equivocated on this question. Balbín Chamorro $(2006,144)$ says these magistrates are "quizás ... ajenos ... [a] los castellani toletenses". Rodríguez Colmenero (1996, 175 and n. 280) asserts that they are magistrates of the castellum, the counterparts of magistri pagi, unless they are magistrates of the civitas Lougeiorum ${ }^{38}$. Melchor Gil (2011, 156) calls them "magistrados ¿de los lougei?". Dopico Caínzos and Santos Yanguas (2013, 185) describe them as "los principales de la comunidad": but of which community, the civitas or the castellum? ${ }^{39}$. The unfortunate truth is, we cannot know for certain. If these $M A G$ officials are representatives of the civitas Lougeiorum, they should be magistratus, just like those of the Zoelae ${ }^{40}$.

If, however, the $M A G$ officials on the $\mathrm{O}$ Courel tablet are representatives of the castellum, a different solution is in order. Since most towns of pre-Roman origin were situated on hilltops and would have been protected by circuit walls, the basic difference between a castellum, or fortified hilltop settlement, and an oppidum was one of size. There is no way that the castellum Toletensium can be compared with substantial towns like Munigua or Asturica Augusta. Castella were not independent towns with magistrates, but were part of a gens or civitas whose political hierarchy (to judge from the surviving evidence) probably consisted of a princeps ${ }^{41}$ and magistratus. A castellum is more closely comparable to a vicus; indeed, some inscriptions refer to the inhabitants of castella as vicani (never oppidani) ${ }^{42}$. It is therefore to be expected that castella, like vici and pagi, would have had magistri. An example is provided by the mag(ister) castelli Phuensium in Numidia (CIL VIII, 6292, 19281 = ILAlg. II, 8962, 8956) ${ }^{43}$. Although some African castella became sufficiently large or important by the Late Empire to assume the title of res publica ${ }^{44}$, this phenomenon is not attested in Hispania. Thus, if the $M A G$ officials in the inscription from $\mathrm{O}$ Courel are representatives of the castellum Toletensium, they should probably be seen as mag(istri).

37 Cf. "los Lougeis del castello Toletense" (Santos Yanguas 1985, 19); "los castellani Toletenses pertenecientes al pueblo de los Lougei" (Orejas et al. 2001, 91).

38 "poseen [magistrados] también, a su nivel, los castella, como parece deducir de la primera de las tabulae del Caurel, viniendo a ser una réplica de los contemporáneos magistri pagi... A no ser Latinus Ari y Aius Temari fuesen los magistri de la civitas de los Lougei que ... podrían ser que verdaderamente sancionan el pacto."

39 The same article (p. 181, table) lists both the castellum Toletum and civitas Lougeiorum as the "comunidades" involved in this transaction.

40 Note, however, that in the inscription of A.D. 1 cited above, the civitas Lougeiorum is represented by legati, not magistratus.

41 E.g. "[Vecc]o Veci f. princeps Co[pororum]" (CIL II, 2585); "Nicer Clutosi (f.) principis Albionum" ( $A E$ 1946, 121); "Doviderus Amparami f. princeps Cantabrorum" ( $A E$ 1997, $875=H E p$ 7, 380). But the supposed "pr(inceps) Argailo(rum)" (CIL II,
5762) is a misreading: see $A E 1994,1006=H E p$ 5, 656(b). See above, n. 22, on castella being attached to civitates.

42 E.g. the vikani consistentes castell[i] Veluniate on the Antonine Wall in Britain $(A E 1958,105=A E$ 1962, $249=R I B$ 3503) or the vicani veteres consistentes castelli Mattiacorum near Mainz (CIL XIII, 6740a, $7250,7301,11804)$. Of course, not all vici were hillforts: Florus Epit. 2,7 distinguishes "vicos, oppida, castella" in Sicily.

$43 \mathrm{On}$ the equivalence of magister castelli and magister pagi in the context of the Phuenses, see Gascou 1983, 203-204.

44 E.g. castellum Biracsaccarensium (AE 1904, 145 = CIL VIII, 23849); castellum Mastar(ensium) (CIL VIII, 6356 = ILAlg. 10130); castellum Subzuaritanum (CIL VIII, $6002=$ ILAlg. 7384); castellum Tidditanorum (AE 1969/70, 693); castellum Zugal (AE 1930, 55 = ILAlg. 8377). On Late Roman castella see Martínez Melón 2006, 123-125. 


\section{Conclusions}

There is no doubt that the abbreviation $M A G$, when referring to the officials of religious or professional collegia, stands for mag(istri). The civil officials in charge of a vicus, pagus or castellum would also be mag(istri). But Hübner and many subsequent scholars have assumed that $M A G$, when referring to the civil officials of a peregrine town, likewise represents magistri. While Rodríguez Neila (1995) and some later investigators have championed the idea that $M A G$ in this context means magistratus, there has been no consensus on the issue, nor a formal argument in favour of such an interpretation. On the contrary, as we have seen, a large number of recent scholars persist in seeing these $M A G$ officials as magistri. This article has endorsed the concept that peregrine towns, variously known as civitates, res publicae or oppida stipendiaria, had magistratus, not magistri, at their helm. This idea is reinforced by several examples in which local officials are explicitly labelled magistratus. These towns had not yet received municipal status, which in most cases would have been granted under the Flavians, and their magistrates were not Roman citizens, except in three cases where a magistrate's career seems to have spanned the transition from peregrine town to municipality. Therefore, in the inscriptions from Capera, Aritium Vetus, civitas Igaeditanorum, Munigua, Aratispi, Herrera de Pisuerga (referring to the civitas Maggaviensium), Paredes de Nava (referring to the civitas Palantina), Clunia, Arellano (referring perhaps to Curnonium) and Complutum we should understand mag(istratus). That gentes (also known as civitates) had magistratus is unequivocally demonstrated by the inscription of the Zoelae. If the guarantors of the $\mathrm{O}$ Courel tablet are officials of the civitas Lougeiorum, they too should be mag(istratus).

However, in situations involving officials of a vicus, pagus or castellum rather than an oppidum, we should interpret $M A G$ as mag(istri). This would apply to the inscription from the probable vicus of Carcuvium, and also to the $\mathrm{O}$ Courel inscription if the officials named are those of the castellum Toletensium. The pagus officials on the Agón bronze are called both $M A G$ and magistri. Although the votive inscriptions from Sisapo and La Milla del Río (referring to Asturica Augusta) might involve cult officials (magistri) rather than magistrates, a good argument can be made that they are actually magistratus, since these officials were, in peregrine communities, the equivalent of the duovirs who were in charge of religion in privileged municipalities.

In the case of the inscriptions from Capera, Complutum and possibly Clunia, the careers of these officials began before the grant of privileged status and continued after, so that they were mag(istratus) while the town was still unprivileged, and duoviri or flamines of the imperial cult thereafter. The inscriptions of these three men, all of whom acquired Roman citizenship, furnish valuable evidence for the romanization of local élites ${ }^{45}$.

\section{BIBLIOGRAPHY}

Abascal palazón, J. M., 2002, «Ataecina», in: Religióes da Lusitânia: Loquuntur saxa, Lisboa: Museu Nacional de Arqueologia, 53-60.

Alföldy, G., 1969, Fasti Hispanienses, Wiesbaden: F. Steiner.

—, 1987a, «Epigraphica Hispanica IX: Inschriften aus Ciudad Real», ZPE 67, 225-248.

45 I am grateful to the referees of Veleia for suggesting various improvements to this article. 
—, 1987b, Römisches Städtewesen auf der neukastilischen Hochebene, Heidelberg: C. Winter.

Almeida, F. DE, 1956, Egitânia: História e arqueologia, Lisboa: Universidade de Lisboa.

Alonso Ávila, Á., Crespo Ortiz, S., 1999, Corpus de inscripciones romanas de la provincia de Salamanca, Valladolid: Los autores.

Andreu Pintado, J., 2003, «Incidencia de la municipalización flavia en el conventus Caesaraugustana», Salduie 3, 163-185.

—,2006, "Munificencia y promoción política de las élites hispanas en época flavia: Ideología y procedimientos», in: J.F. Rodríguez Neila, E. Melchor Gil (eds.), Poder central y autonomía municipal: La proyección pública de las élites romanas de Occidente, Córdoba: Universidad de Córdoba, 373-403.

Arias Vilas, F., Le Roux, P., Tranoy, A., 1979, Inscriptions romaines de la province de Lugo, Paris: de Boccard.

Armendáriz Martija, J., 2006, «Bases arqueológicas para la localización de la ciudad vascona de Curnonium en Los Arcos (Navarra)", Trabajos de Arqueologia Navarra 19, 85-108.

Balbín Chamorro, P., 2006, Hospitalidad y patronato en la Peninsula Ibérica durante la antigüedad, Valladolid: Junta de Castilla y León.

Beltrán Lloris, F., 2001, "La hospitalidad celtibérica: Una aproximación a partir de la epigrafía latina», Palaeohispanica 1, 35-62.

—,2003, «Una variante provincial del hospitium: Pactos de hospitalidad y concesión de la ciudadanía local en la Hispania Tarraconense», in: S. Armani, B. Hurlet-Martineau, A.U. Stylow (eds.), Epigrafía y sociedad en Hispania durante el Alto Imperio: Estructuras y relaciones sociales, Alcalá de Henares: Universidad de Alcalá, 33-56.

—,2006, «An irrigation decree from Roman Spain: The Lex Riui Hiberiensis», Journal of Roman Studies 96, 147-197.

Blázquez, J. M., 1965, Caparra, [Excavaciones Arqueológicas en España 34], Madrid: Ministerio de Educación Nacional.

Bonnin, J., 2010, «Les horologia romana en Hispanie, mobilier, histoire et realités archéologiques», AEspA 83, 183-198.

Bravo Castañeda, G., 1985, «Avance sobre un nuevo bronce del año 134, hallado en Montealegre (Valladolid)», Gerión 3, 309-316.

Caballos Rufino, A., 1998, «Los equites y la dinámica municipal de la Lusitania, I: Catálogo prosopográfico», in: L. Hernández Guerra, L. Sagredo San Eustaquio (eds.), El proceso de municipalización en la Hispania romana, Valladolid: Universidad de Valladolid, 205-233.

Canto, A. M., 1996, "Oppida stipendiaria: Los municipios flavios en la descripción de Hispania de Plinio», Cuadernos de Prehistoria y Arqueología 23, 212-243.

Carbonell, J., Gimeno, H., Stylow, A. U., 2007, «Pons Traiani, Qantara es-Saif, puente de Alcántara: Problemas de epigrafía, filología e historia», in: M. Mayer i Olivé, G. Baratta, A. Guzmán Almagro (eds.), XII Congressus internationalis epigraphiae Graecae et Latinae (Barcelona 2002), Barcelona: Institut d'Estudis Catalans/Universitat de Barcelona/Universitat Autònoma de Barcelona, 247-257.

Castillo, C., 1993, «Miscelánea epigráfica hispano-romana II», SDHI 59, 299-313.

—,2013, «La munificencia cívica de un emeritense $(A E$ 1967, 144)», in: E. Melchor Gil, A.D. Pérez Zurita, J.F. Rodríguez Neila (eds.), Senados municipales y decuriones en el Occidente romano, Sevilla: Universidad de Sevilla/Universidad de Córdoba, 295-302.

—, Gómez-Pantoja, J., Mauleón, M. D., 1981, Inscripciones romanas del Museo de Navarra, Pamplona: Diputación Foral/Institución Príncipe de Viana.

Corell Badía, J. L., Corell i Vicent, J., 1994, «Nueva “tabula patronatus” procedente de la Bética», Epigraphica 56, 59-67.

Cugusi, R., 1985, Aspetti letterari dei Carmina Latina Epigraphica, Bologna: Pàtron.

Curchin, L. A., 1990, The local magistrates of Roman Spain, Toronto: University of Toronto Press.

Delgado Delgado, J. A., 2014, «El sacerdocio salio de Sagunto: La recepción del programa religioso de Augusto en un municipio de Hispania Citerion, Veleia 31, 143-162.

des Boscs-Plateaux, F., 2005, Un parti hispanique à Rome?, Madrid: Casa de Velázquez. 
Díaz Ariño, B., 2004, «Heisce magistreis: Aproximación a los collegia de la Hispania republicana a través de sus paralelos italianos y delios», Gerión 22, 447-478.

Diego Santos, F., 1986, Inscripciones romanas de la provincia de León, León: Diputación Provincial.

Dopico Caínzos, M. D., Santo Yanguas, J., 2013, «Los magistrados de los documentos de hospitalidad en Hispania», in: E. Ortiz de Urbina Álava (ed.), Magistrados locales de Hispania: Aspectos históricos, jurídicos, lingüisticos, [Anejos de Veleia, Acta 13], Vitoria-Gasteiz: Universidad del País Vasco, 171-187.

D’Ors, A., 1953, Epigrafía jurídica de la España romana, Madrid: Instituto Nacional de Estudios Jurídicos.

—, 1960, «Miscelánea epigráfica», Emerita 28, 141-149.

—, 1961, «Miscelánea epigráfica: Los bronces de Mulva», Emerita 29, 203-218.

EnCarnação, J. d', 1984, Inscriçôes romanas do conventus Pacensis, Coimbra: Instituto de Arqueologia.

—,2007, «O culto imperial na epigrafia da Lusitânia ocidental: Novidades e reflexóes», in: T. Nogales, J. González (eds.), Culto imperial: Política y poder, Rome: L'Erma di Bretschneider, 349-368.

—,2013a, "Gentes e divindades na Lusitânia pré-romana ocidental», Palaeohispanica 13, 209-215.

—,2013b, "Novidades epigráficas dos conventus Scallabitanus e Pacensis», in: J. López Vilar (ed.), Actes $1^{\text {er }}$ Congrés internacional d'arqueologia i món antic (Tarragona, 29-30 de novembre i 1 de desembre de 2012), Tarragona: Fundació Privada Mútua Catalana, 125-133.

Étienne, R., 1958, Le culte impérial dans la Péninsule Ibérique, Paris: de Boccard.

—, 1992, "L'horloge de la civitas Igaeditanorum et la création de la province de Lusitanie», REA 94, 355-362.

Fasolini, D., 2012, Le tribù romane della Hispania Tarraconensis: L'ascrizione tribale dei cittadini romani nelle testimonianze epigrafiche, Milano: Vita e Pensiero.

Fernández Aller, M. ${ }^{a}$ C., 1978: Epigrafía y numismática romanas en el Museo Arqueológico de León, León: Colegio Universitario de León.

Ferrer Maestro, J. J., 1991, «En torno a la ejecución de las obras públicas en la Hispania romana: Promotores y artifices», in: Millars: Geografia-Historia 14, 102-117.

GaLSTERer, H., 1971, Untersuchungen zum römischen Städtewesen auf der Iberischen Halbinsel, [Madrider Forschungen 8], Berlin: de Gruyter.

García y Bellido, A., 1966, "Tessera hospitalis del año 14 de la Era hallada en Herrera de Pisuerga», BRAH 158, 149-163.

—, 1974, "Arcos honoríficos romanos en Hispania», in: Colloquio italo-spagnolo sul tema: Hispania romana (Roma, 15-16 maggio 1972), Roma: Accademia Nazionale dei Lincei, 7-24.

García Fernández, E., 2000, «Plinio y los oppida stipendiaria: A propósito de un artículo de Alicia M. ${ }^{a}$ Canto", Gerión 18, 571-591.

Garcia Martínez, S. M. a, 1997, «Regulamento jurídico no Noroeste peninsular», Douro: Estudos \& Documentos 4, 39-62.

Gascou, J., 1983, «Pagus et castellum dans la Confédération Cirtéenne», Antiquités Africaines 19, 175-207.

Gómez-Pantoja, J. L., 2003, "Ex ultima Celtiberia: Desarrollo municipal y promoción social en las viejas ciudades arévacas», in: C. Castillo, J.F. Rodríguez Neila, F.J. Navarro (eds.), Sociedad y economía en el Occidente romano, Pamplona: Universidad de Navarra, 231-282.

Gómez Vila, J., 2009, Epigrafía romana de la provincia de Lugo, London: Lulu Enterprises.

GonzÁlez-Conde, M. P., 1985, «Promoción jurídica y administración municipal de Complutum en el Alto Imperio", Lucentum 4, 133-146.

GonZÁlez Fernández, J., 1988, «The first oath pro salute Augusti found in Baetica», ZPE 72, 113-127.

—, 1990, Bronces jurídicos romanos de Andalucía, Sevilla: Junta de Andalucía.

González Herrero, M., 2002, «M. Fidius Fidi f. Quir(ina) Macer, benefactor en Capera», Gerión 20, 417-433.

GonzÁlez RodríGuez, M. C., 1986, Las unidades organizativas indígenas del área indoeuropea de Hispania, [Anejos de Veleia, Series Maior 2], Vitoria/Gasteiz: UPV/EHU.

—, 1994, «Reflexiones sobre las unidades organizativas indígenas del área indoeuropea», in: M.C. González [Rodríguez], J. Santos [Yanguas] (eds.), Las estructuras sociales indígenas del Norte de la Península Ibérica [Anejos de Veleia, Acta 1], Vitoria/Gasteiz: UPV/EHU. 
—,2006, Los astures y los cántabros vadinienses: Problemas y perspectivas de análisis de las sociedades indígenas de la Hispania indoeuropea, 2a ed., [Anejos de Veleia, Series Minor 10], Vitoria-Gasteiz: UPV/EHU.

—,2014, "Los santuarios del territorio en las ciuitates de la Asturia augustana: El ejemplo del deus Vagus Donnaegus», in: J. Mangas Manjarrés, M.A. Novillo López, (eds.), Santuarios suburbanos y del territorio de las ciudades romanas, Madrid: Instituto de Investigación en Ciencias de la Antigüedad de la Universidad Autónoma de Madrid, 205-233.

González Román, C., 2002-2003, «La Lex Irnitana y la onomástica de los municipios flavios», Memorias de Historia Antigua 23-24, 77-102.

Grupo Mérida, 2003, Atlas antroponimico de la Lusitania romana, Mérida/Bordeaux: Fundación de Estudios romanos/Ausonius Éditions.

Hernández Guerra, L., 1994, Inscripciones romanas en la provincia de Palencia, Valladolid/Palencia: Universidad de Valladolid/Diputación Provincial de Palencia.

—,2001, Epigrafia romana de la provincia de Salamanca, Valladolid: Universidad de Valladolid.

—,2008, "Algunas consideraciones sobre municipios flavios en la Meseta septentrional», Gerión 26, 407-438.

Hurtado de San Antonio, R., 1977, Corpus provincial de inscripciones latinas (Cáceres), Cáceres: Diputación Provincial.

Knapp, R. C., 1992, Latin inscriptions from Central Spain, Berkeley/Los Angeles/Oxford: University of California Press.

Lambrino, S., 1956, «Les inscriptions latines inédites du Musée Leite de Vasconcelos», O Arq. Port. n.s. 3, 5-73.

Le Roux, P., 2009, "Cultos y religión en el noroeste de la Península Ibérica en el alto Imperio romano», $V e$ leia 26, 265-285.

—,2010, «Tribus romaines et cités sous l'Empire: Épigraphie et histoire», in: Atti della XVe Rencontre sur l'épigraphie (Bari 8-10 ottobre 2009), Bari: Edipuglia, 113-121.

López Melero, R., 1986, «Nueva evidencia sobre el culto de Ategina: El epígrafe de Bienvenida», in: I Jornadas sobre manifestaciones religiosas en la Lusitania, Cáceres: Universidad de Extremadura, 93-112.

Lostal Pros, J., 1992, Los miliarios de la provincia Tarraconense, Zaragoza: Institución Fernando el Católico.

Mangas, J., 1997, "Financiación y administración de los sacra publica en la lex Ursonensis», SHHA 15, 181-195.

—,2000, "Castellum, gens y civitas en el edicto de Augusto (15 a.C.)», in: F.J. Sánchez-Palencia, J. Mangas (coords.), El edicto del Bierzo: Augusto y el noroeste de Hispania, León: Fundación Las Médulas, 47-62.

Mantas, V. G., 1988, "Orarium donauit Igaeditanis: Epigrafia e funçôes urbanas numa capital regional lusitana», in: I Congreso peninsular de historia antigua, vol. II, Santiago de Compostela: Universidade de Santiago de Compostela, 415-439.

—,2000, "A sociedade luso-romana do município Ammaia», in: J.-G. Gorges, T. Nogales Basarrate, Sociedad y cultura en Lusitania romana: IV mesa redonda internacional, Badajoz: Junta de Extremadura, 391-420.

Mañanes Pérez, T., 1982, Epigrafía y numismática de Astorga romana, Salamanca: Universidad de Salamanca.

Marco Simón, F., 2002, «Vota omnia finibus. La tésera de Herrera de Pisuerga y la ritualización de los pactos de la Hispania indoeuropea», Palaeohispanica 2, 169-188.

MARINer, S., 1952, Inscripciones hispanas en verso, Barcelona: Escuela de Filología.

Martínez Melón, J. I., 2006, «El vocabulario de los asentamientos rurales (siglos I-IX d.C.)», in: A. Chevarría, J. Arce, G.P. Briogiolo, Villas tardoantiguas en el Mediterráneo occidental [Anejos de AEspA XXXIX], Madrid: Centro de Estudios Históricos, 113-131.

Mayer, M., Velaza, J., 1994, «El carmen epigraphicum de Arellano (Navarra)», Príncipe de Viana 203, 515-526. 
Melchor Gil, E., 2011, «Sobre los magistrados de las comunidades hispanas no privilegiadas (s. III a.C.s. I d.C.)», in: A. Sartori, A. Valvo (eds.), Identità e autonomie nel mondo romano occidentale Iberia-Italia Italia-Iberia, Faenza: Fratelli Lega Editori, 151-171.

—, 2013, «Instituciones de gobierno de las comunidades hispanas no privilegiadas (s. III a.C.-s. I d.C.): Senatus y magistratus», in: E. Ortiz de Urbina Álava (ed.), Magistrados locales de Hispania: Aspectos históricos, jurídicos, lingüisticos, [Anejos de Veleia, Acta 13], Vitoria-Gasteiz: Universidad del País Vasco, 135-158.

NavascuÉs, J. M. DE, 1934, «Inscripciones hispano-romanas», AEspA 10, 189-206.

Nesselhauf, H., 1960, «Zwei Bronzeurkunden aus Munigua», Madrider Mitteilungen 1, 142-154.

Olivares Pedreño, J. C., 2002, Los dioses de la Hispania céltica, [Bibliotheca Archaeologica Hispana 15], Madrid/Alicante: Real Academia de la Historia/Universidad de Alicante.

—,2002-2003, «Religión romana y religión indígena en las ciudades de la Céltica hispana», Lucentum 21-22, 207-225.

Orejas, A., Sastre, I., Sánchez Palencia, F.-J., Plácido, D., 2001, «El edicto de Augusto del Bierzo y la primera organización romana del Noroeste peninsular», in: F.-J. Sánchez Palencia, J. Mangas (eds.), El edicto del Bierzo: Augusto y el Noroeste de Hispania, Ponferrada: Fundación Las Médulas.

Ortiz de Urbina ÁlaVA, E., 2013, «Sobre los procesos de (re)organización institucional cívica en Hispania», in: E. Ortiz de Urbina Álava (ed.), Magistrados locales de Hispania: Aspectos históricos, jurídicos, lingüisticos, [Anejos de Veleia, Acta 13], Vitoria-Gasteiz: Universidad del País Vasco, 279-308.

Palol, P., Vilella, J., 1987, Clunia II: La epigrafía de Clunia [Excavaciones Arqueológicas en España 150], Madrid: Ministerio de Cultura.

Pastor Muñoz, M., 1977, Los astures durante el imperio romano, Oviedo: Diputación Provincial.

Pérez Zurita, A. D., 2011, La edilidad y las élites locales en la Hispania romana, Córdoba/Sevilla: Universidad de Córdoba/Universidad de Sevilla.

Rabanal Alonso, M. A., 1998, «Las formas de organización ciudadana en las comunidades urbanas del conventus astur», in: L. Hernández Guerra, L. Sagredo San Eustaquio (eds.), El proceso de municipalización en la Hispania romana, Valladolid: Universidad de Valladolid, 103-138.

Ramírez SÁdABA, J. L., 2006, "Las ciudades vasconas según las fuentes literarias y su evolución en la tardoantigüedad», in: Espacio y tiempo en la percepción de la antigüedad tardía, [Antigüedad y cristianismo 23], Murcia: Universidad de Murcia, 185-199.

ReID, J. S., 1913, The municipalities of the Roman empire, Cambridge: Cambridge University Press.

Rodríguez Álvarez, P., 1993, «Sobre las gentes de Hispania», in: J. Untermann, F. Villar (eds.), Lengua y cultura en la Hispania prerromana, [Acta Salmanticensia 251], Salamanca: Universidad de Salamanca, 445-460.

Rodríguez Colmenero, A., 1996, «Pueblos prerromanos del convento jurídico Lucense: Organización sociopolítica y distribución territorial», in: A. Rodríguez Colmenero (coord.), Lucus Augusti, I: El amanecer de una ciudad, A Coruńa: Fundación Pedro Barrié de la Maza, 129-242.

Rodríguez Neila, J. F., 1993, «Gestión administrativa en las comunidades indígenas hispanas durante la etapa pre-municipal», in: J.F. Rodríguez Neila (ed.), Actas del I Coloquio de historia antigua de Andalucía, Córdoba: Monte de Piedad y Caja de Ahorros de Córdoba, 385-412.

—, 1995, «Organización administrativa de las comunidades hispanas y magistraturas monetales», in: M.P. García-Bellido, R.M. Sobral Centeno (eds.), La moneda hispánica: Ciudad y territorio, [Anejos de AEspA XIV], Madrid: Centro de Estudios Históricos, 261-273.

Rosado Martín, M. C., 2010, «El juramento de fidelidad a Octaviano del año 32 a.C.», El Futuro del Pasado $1,337-347$.

Royo Martínez, M. M., 2010, «Onomástica y sociedad en la epigrafía latina antigua de la Comunidad Autónoma de Madrid», Espacio, Tiempo y Forma, serie II, Historia Antigua, 23, 369-394.

Ruiz Trapero, M., 2001, Inscripciones latinas de la Comunidad Autónoma de Madrid (siglos I-VIII), Madrid: Comunidad de Madrid. 
Salinas de Frías, M., 2001, Los vettones: Indigenismo y romanización en el occidente de la Meseta, Salamanca: Universidad de Salamanca.

—, 2013, «Personal onomastics and local society in ancient Lusitania», in: J.L. García Alonso (ed.), Continental Celtic word formation: The onomastic data [Aguilafuente 197], Salamanca: Universidad de Salamanca, 17-35.

Santero Santurino, J. M., 1978, Asociaciones populares en Hispania romana, Sevilla: Universidad de Sevilla.

Santos Yanguas, N., 1985, Comunidades indígenas y administración romana en el Noroeste hispánico, Vitoria-Gasteiz: Universidad del País Vasco.

Schäfer, N., 2000, Die Einbeziehung der Provinzialen in den Reichsdienst in augusteischer Zeit, Stuttgart: F. Steiner.

Solana Sainz, J. M., 1981, Los cántabros y la ciudad de Iuliobriga, Santander: Librería Estudio.

TARPIn, M., 2002, Vici et pagi dans l'Occident romain, [Collection de l'École Française de Rome 299], Paris: École Française de Rome.

Tissot, Сн., 1883, «Inscriptions découvertes par M. Fonssagrives en Tunisie», Bulletin Épigraphique 3, 213-221.

Torrent Ruiz, A. J., 2013, «Los magistri pagi en la Lex Rivi Hiberiensis: naturaleza y funciones», in: Direito romano: Poder e direito, [XV Congresso internacional de direito romano], Coimbra: Coimbra Editora, 109-129.

Tranoy, A., 1981, La Galice romaine, Paris: de Boccard.

Vallejo Ruiz, J. M., 2005, Antroponimia indígena de la Lusitania romana, [Anejos de Veleia, Series Minor 23], Vitoria-Gasteiz: Universidad del País Vasco.

VAz, J. L. I., 1997, A civitas de Viseu: Espaço e sociedade, Coimbra: Comissão de Coordinação da Região Centro.

Wiegels, R., 1985, Die Tribusinschriften des römischen Hispanien, [Madrider Forschungen 13], Berlin: de Gruyter.

ZeIdleR, J., 2007, "Celto-Roman contact names in Galicia», in: D. Kremer (ed.), Onomástica galega, con especial consideración da situación prerromana, [Verba Anexo 58], Santiago de Compostela: Universidade de Santiago de Compostela, 41-56. 